\title{
The road infrastructure development impact on the economy of the region
}

\author{
Olesia Lykova* \\ Don State Technical University, 344002, Rostov-on-Don, Russia
}

\begin{abstract}
The subject of the research is the road infrastructure development; the purpose of the study is to analyze the road network of the region as an element of its road infrastructure, to analyze the development of the road infrastructure using quantitative and qualitative criteria based on the regional road network current state assessment (using the example of the Krasnodar Territory). The construction and reconstruction of a capital construction object - highways will lead to an improvement in the conditions for the implementation of transport links, a decrease in accidents and an increase in traffic capacity, which will increase the circulation speed on this road section, and, as a result, reduce transport costs.
\end{abstract}

\section{Introduction}

The state of the road infrastructure in modern conditions affects the economy of the region and this is due to a number of reasons. First of all, this is insufficient financing of public services, the absence of commercialization mechanisms, simultaneously with imbalances in the federal and municipal budgets, leads to an underproduction of services, which means incomplete satisfaction of the population needs, a decrease in its mobility and, ultimately, welfare.

Most of these problems cannot be solved by the private sector and the market, which requires the active participation of municipalities in the production of public goods and services. However, the forms of this participation can be different and depend, first of all, on the division of powers, financial responsibilities and interests between the public and private sectors. It is obvious that the substantiation of effective mechanisms of commercialization is the most urgent task here.

However, the difficulty lies in the selection of a competitive regime, such as contracting, interaction of the municipality with the private sector and its implementation in an optimal way. This makes it necessary to justify the implementation and identify the features of the implementation of organizational, economic and management measures aimed at the formation and development of the road network in the region.

Regions play a key role in the construction of infrastructure, especially the roads, and they, as a rule, are developed within the framework of federal programs. In the area of transport infrastructure development, the priority areas of the ministry are to promote

\footnotetext{
${ }^{*}$ Corresponding author: olesia_post@mail.ru
} 
uniform policies and standards, coordinate efforts at various levels of government and create federal infrastructure. The Transport Strategy of Russia for the period up to 2030, approved by the Government of the Russian Federation at the end of last year, has recently received an update. The key factor in the implementation of this strategy is the state program for the transport system development. Coordination Councils for the transport hubs' development in the Southern Federal District are a good example of effective and efficient cooperation between the ministry and the regions.

Using the example of the Krasnodar Territory, we will consider the state of the road infrastructure and determine how the state of the roads affects the economy of the region. Krasnodar Territory has an advantageous location and is a connecting artery between major cities of the country. The length of highways in the Krasnodar Territory is $32,000 \mathrm{~km}$. With a hard surface, $26,000 \mathrm{~km}$ of which about $13,000 \mathrm{~km}$ are roads with an improved surface. About $3759.5 \mathrm{~km}$ of roads do not meet the regulatory requirements of the local roads [1]. It would be worth noting that this indicator has decreased by $3 \%$ over the past 3 years. This was achieved at the expense of the federal budget in the implementation of long-term (regional and municipal) targeted programs, which made it possible to improve the quality of road surfaces and reach a new level of development of the region's transport infrastructure.

But nevertheless, as follows from the data presented, the existing state of public highways of local importance is characterized by serious shortcomings and does not correspond to the needs for transportation.

The main problem of the network of local highways of the region is, first of all, in the presence of numerous sections of roads that do not have a hard surface and do not meet regulatory requirements due to the inconsistency of the main technical parameters of the existing or expected future traffic intensity, or due to inconsistency with other transport and operational condition of roads.

In order to determine the level of quality and traffic flow, a list of requirements for the road networks has been developed:

- means of organizing the circulation of pedestrians and cyclists;

- average daily traffic intensity of freight and passenger traffic for calculating the number of lanes (with a population of more than 50 thousand people, a multi-lane road is being designed);

- -ensuring road safety, reducing accidents;

- vehicle impact devices;

- transit potential and passenger traffic directly depend on the roads' quality. This requirement demonstrates the direct dependence of road transport on the quality of roads, and the possibility of financial support for roads, on the economic development of the region, due to the profit from transport;

- quality of coverage, for safe traffic on all sections of the road network.

The research of domestic scientists - Z. Magrupov, A. Eremeev, I. Tapilin [2, 3] is devoted to the development of transport infrastructure. The mechanism of the road network development in the region was investigated in the works of I. Evstigneev, T. Zolotukhin, N. Fatakhutdinov $[4,5]$.

\section{Results}

Any region is interested in developing and improving the conditions for the implementation of transport links, increasing the throughput of high-speed roads, reducing accidents and the negative impact of transport on the environment, increasing the speed of vehicles and reducing transport costs. All these conditions form a characteristically new structure for the 
development of road infrastructure in the region and pose qualitatively new tasks in the study of the effectiveness of the analyzed process in the field of demand and satisfaction with the road infrastructure of the region by road users. And on the other hand, a comprehensive analysis of the dissatisfactioncriteria with the road infrastructure is necessary, since it is necessary to determine the internal effects that hinder the road network development and, as a consequence, the region's economy. Therefore, it is necessary to create such economic conditions necessary for updating and realizing the potential of the road infrastructure, which would give a vector of development to various sectors of the economy by improving the quality of transportation.

The expected economic effect received by road users as a result of the implementation of design solutions in the construction or reconstruction of roads is the sum of the transport effect [6] (Fig. 1).

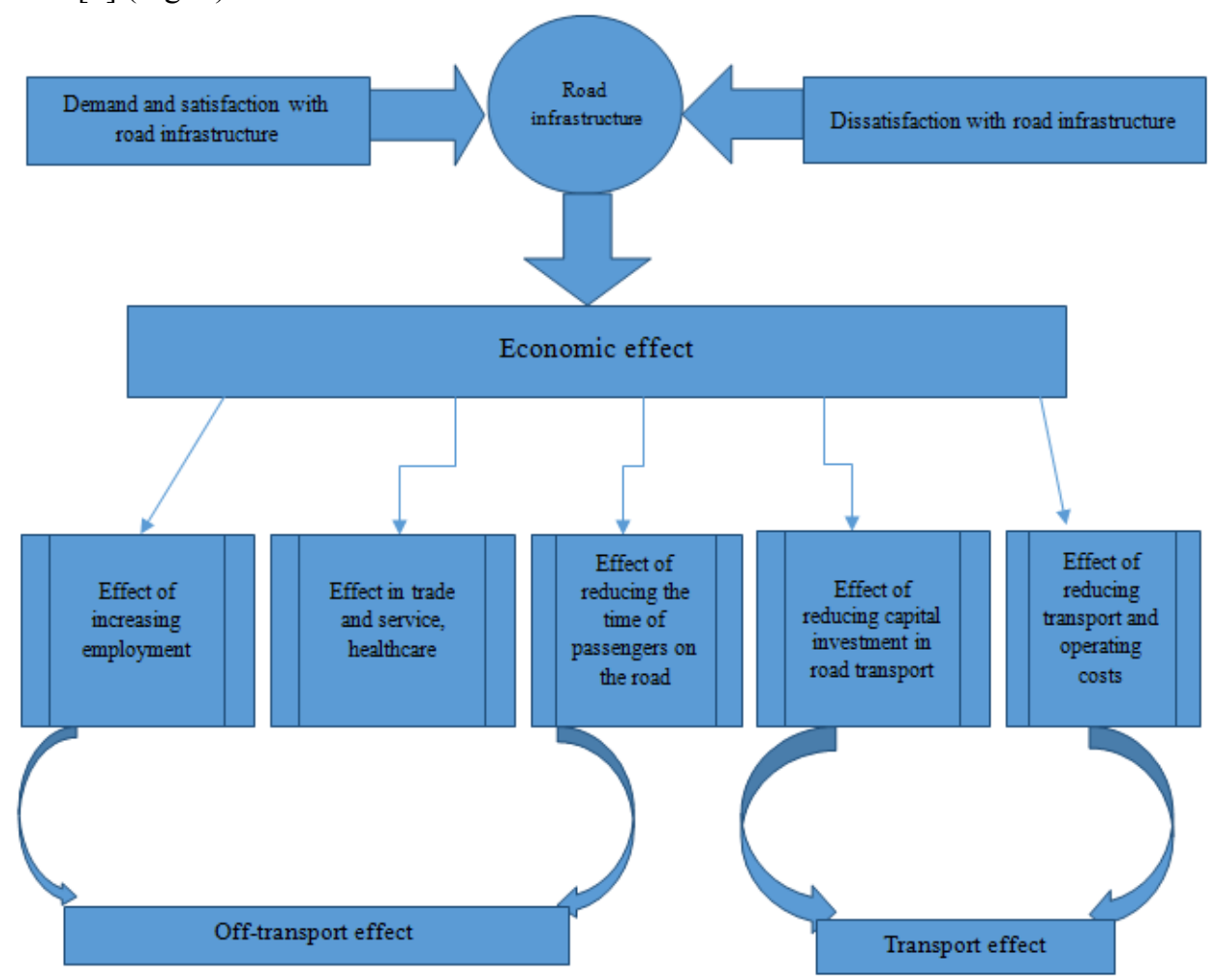

Fig. 1. Impact of economic effect on the road infrastructure development.

The transport effect consists of the effect obtained from a reduction in transport and operating costs due to a decrease in the cost of vehicle mileage per $1 \mathrm{~km}$, the effect of a reduction in capital investments in road transport and annual additional capital investments that ensure an increase in the volume of freight traffic. The off-transport effect from improving road conditions is formed from the effect in the sphere of enhancing entrepreneurial activity in trade, in health care, in increasing employment of the population and reducing the time spent by passengers on the way due to an increase in traffic speeds and a decrease in losses from road accidents while improving the conditions and increasing traffic comfort [7].

To effectively solve social problems, it is necessary to pay attention to the fact that investments in road infrastructure contribute to the entrepreneurial activity activation, reduce the negative impact of road infrastructure on the environment, and reduce the 
number of accidents. But nevertheless, the main goal of the arrangement and reconstruction of roads remains the capacity of transport, which solves a number of problems, such as reducing travel time, traffic intensity, the possibility of increasing speed. As an example, let us compare the traffic intensity before the reconstruction of the M-4 "Don" road segment from $\mathrm{km} 1459+805$ to $\mathrm{km} 1542+215$ and further. At the same time, it is necessary to take into account and analyze the size of traffic flows for each of the road sections, depending on the type of transport (trucks, cars).

To determine the seasonal coefficient of fluctuations in traffic intensity, the distribution of traffic intensity was analyzed depending on the type of transport [8]. The results of traffic intensity monthly measurements carried out by the road maintenance service made it possible to calculate the ratio of monthly traffic intensity by transport mode to the average annual value.

Table 1. Results of control measurements of traffic intensity, June 2015

\begin{tabular}{|c|c|c|c|c|c|}
\hline \multirow{2}{*}{$\begin{array}{l}\text { Location of the } \\
\text { counting point } \\
\text { (highwayM-4 } \\
\text { "Don") }\end{array}$} & \multicolumn{2}{|c|}{$\begin{array}{l}\text { Time spending } \\
\text { accounting }\end{array}$} & \multirow{2}{*}{$\begin{array}{c}\begin{array}{c}\text { Intensity } \\
\text { circulation, } \\
\text { units. }\end{array} \\
\text { Towards } \\
\text { Novoros- } \\
\text { siysk }\end{array}$} & \multicolumn{2}{|c|}{ Adjoining road } \\
\hline & day & hour & & Name & $\begin{array}{c}\text { Intensity } \\
\text { circulation, } \\
\text { units }\end{array}$ \\
\hline 1 & 2 & 3 & 4 & 5 & 6 \\
\hline $\begin{array}{c}1 . \mathrm{km} \\
1503+750\end{array}$ & 15.07 .2015 & $\begin{array}{c}09: 20 \\
10: 20\end{array}$ & 1605 & $\begin{array}{c}\text { highway M- } \\
4 \text { "Don" } \\
\text { Aderbievka }\end{array}$ & 255 \\
\hline \multirow{4}{*}{ 2. $\mathrm{km} 1504+600$} & \multirow{2}{*}{15.07 .2015} & \multirow{2}{*}{$\begin{array}{l}10: 25- \\
11: 25\end{array}$} & \multirow{2}{*}{2123} & $\begin{array}{l}\text { highway } \\
\text { M-4 "Don } \\
\text { Dzhanhot" }\end{array}$ & 1066 \\
\hline & & & & $\begin{array}{c}\text { Exit to } \\
\text { Aderbievka } \\
\text { village }\end{array}$ & 31 \\
\hline & \multirow{2}{*}{15.07 .2015} & \multirow{2}{*}{$\begin{array}{c}15: 00 \\
16: 00\end{array}$} & \multirow{2}{*}{2172} & $\begin{array}{l}\text { Highway } \\
\text { M-4 "Don } \\
\text { Dzhanhot" }\end{array}$ & 1116 \\
\hline & & & & $\begin{array}{c}\text { Exit to } \\
\text { Aderbievka } \\
\text { village }\end{array}$ & 22 \\
\hline 3. $\mathrm{km} 1504+850$ & 15.07 .2015 & $\begin{array}{c}13: 45- \\
14: 45\end{array}$ & 2339 & Exit to PR & 50 \\
\hline 4. $\mathrm{km} 1505+800$ & 15.07.2015 & $\begin{array}{c}16: 10 \\
17: 10\end{array}$ & 1407 & $\begin{array}{c}\text { Exit to } \\
\text { Gelendzhik } \\
\text { (Lunac- } \\
\text { harsky st.) }\end{array}$ & 1566 \\
\hline
\end{tabular}

Source: compiled by the author based on the research results

After the M-4 Don road segment reconstruction as of 2020 , it can be said that the throughput and traffic intensity increased in the studied sections by $30 \%$. Moreover, the data obtained in the course of measuring the traffic intensity, broken down by the carrying capacity of trucks in the main directions, indicate a significant road traffic of the freight train, especially of medium and low carrying capacity.

Also, when comparing the speed of cars before and after the road segment reconstruction, they differ by an average of $30 \mathrm{~km} / \mathrm{h}$, while the analysis of the route plan 
elements' lists was carried out, which made it possible to determine the actual values of the calculated speeds for the characteristic sections of the road by the curves' radii values in the plan, as well as on serpentine sites. The values of the calculated speeds after reconstruction are given in Table 2.

Table 2. Estimated speeds on the studied road sections

\begin{tabular}{|l|c|c|c|}
\hline \multirow{2}{*}{ Road Portion } & \multicolumn{3}{|c|}{ Speed standard, km / h } \\
\cline { 2 - 4 } & Main portion & Difficult portion & Serpentine portion \\
\hline $\mathrm{km} 1459+805-\mathrm{km} \mathrm{1466+100}$ & 80 & 60 & - \\
\hline $\mathrm{km} 1466+100-\mathrm{km} 1468+200$ & 90 & 60 & - \\
\hline $\mathrm{km} 1468+200-\mathrm{km} 1473+500$ & 70 & 60 & - \\
\hline $\mathrm{km} 1473+500-\mathrm{km} 1476+500$ & 70 & 50 & - \\
\hline $\mathrm{km} 1476+500-\mathrm{km} 1485+300$ & 90 & 60 & - \\
\hline $\mathrm{km} 1485+300-\mathrm{km} 1488+500$ & 90 & 60 & - \\
\hline $\mathrm{km} 1488+500-\mathrm{km} 1494+900$ & 70 & 50 & 30 \\
\hline $\mathrm{km} 1494+900-\mathrm{km} 1499+400$ & 80 & 60 & - \\
\hline $\mathrm{km} 1499+400-\mathrm{km} 1505+650$ & 90 & 60 & - \\
\hline $\mathrm{km} 1513+450-\mathrm{km} 1519+400$ & 90 & 70 & 20 \\
\hline $\mathrm{km} 1531+650-\mathrm{km} 1536+700$ & 80 & 60 & - \\
\hline
\end{tabular}

Source: compiled by the author based on the research results

Taking into account the analysis of the road technological features, the analysis of the traffic intensity on the investigated section of the M-4 "Don" highway from km $1459+805$ to $\mathrm{km} 1542+215$ [9] (Table 3) was carried out, and also the efficiency was considered on the basis of economic research taking into account the toll road bypassing Novorossiysk in the direction of Abinsk - Kabardinka.

The analysis of the reduced average annual daily intensity on the investigated section of the M-4 "Don" highway from $\mathrm{km} 1459+805$ to $\mathrm{km} 1542+215$ under the existing conditions, taking into account the toll road bypassing Novorossiysk and Abinsk Kabardinka, showed that the throughput of vehicles for this direction reduces travel time and makes it possible to reduce traffic intensity and is one of the factors in maintaining the Krasnodar Territory in economic equilibrium.

Table 3. Traffic intensity with current results and taking into account the use of a toll road

\begin{tabular}{|c|c|c|c|c|c|}
\hline \multirow{2}{*}{ Track span name } & \multirow{2}{*}{$\begin{array}{c}\text { Length, } \\
\mathrm{km}\end{array}$} & \multicolumn{4}{|c|}{ Average annual daily traffic intensity, car / } \\
\cline { 3 - 6 } & & Freight & Cars & Buses & Total \\
\hline 1 & 2 & 3 & 4 & 5 & 6 \\
\hline $\begin{array}{l}\text { The beginning of the } \\
\text { route (Arkhipo-Osipovka } \\
\text { village) - Pshada village } \\
\text { adjoining the entrance to }\end{array}$ & 18.10 & $\begin{array}{c}2050- \\
1850\end{array}$ & $\begin{array}{c}4750- \\
4550\end{array}$ & 350 & $7150-6750$ \\
$\begin{array}{l}\text { Beregovoe village and } \\
\text { Betta village }\end{array}$ & & & & & \\
\hline Adjacent to the entrance & 23.20 & $1950-$ & $4700-$ & $250-$ & $6900-7250$ \\
\hline
\end{tabular}




\begin{tabular}{|c|c|c|c|c|c|}
\hline \multirow{2}{*}{ Track span name } & \multirow{2}{*}{$\begin{array}{l}\text { Length, } \\
\mathrm{km}\end{array}$} & \multicolumn{4}{|c|}{$\begin{array}{l}\text { Average annual daily traffic intensity, car / } \\
\text { day }\end{array}$} \\
\hline & & Freight & Cars & Buses & Total \\
\hline $\begin{array}{l}\text { to the village of } \\
\text { Beregovoe and the } \\
\text { village of Betta - the } \\
\text { village of Vozrozhdenie }\end{array}$ & & 2000 & 4950 & 300 & \\
\hline $\begin{array}{l}\text { Vozrozhdenie - adjoining } \\
\text { the entrance to the } \\
\text { village. Divnomorskoe } \\
\text { and the village of } \\
\text { Praskoveevka }\end{array}$ & 3.50 & $\begin{array}{c}2150- \\
2800\end{array}$ & $\begin{array}{c}6600- \\
9250\end{array}$ & $\begin{array}{c}400- \\
600\end{array}$ & $\begin{array}{l}9150- \\
12650\end{array}$ \\
\hline $\begin{array}{l}\text { Adjacent to the entrance } \\
\text { to the village. } \\
\text { Divnomorskoe and the } \\
\text { village of Praskoveevka - } \\
\text { the beginning of the } \\
\text { bypass of Gelendzhik }\end{array}$ & 1.40 & 3800 & 16000 & 1200 & 21000 \\
\hline Bypass of Gelendzhik & 7.75 & 4950 & 18850 & 850 & 24650 \\
\hline Gelendzhik & 1.65 & $\begin{array}{c}6400- \\
4700\end{array}$ & $\begin{array}{c}31200- \\
22400\end{array}$ & $\begin{array}{c}2050- \\
1150\end{array}$ & $\begin{array}{c}40300- \\
28500\end{array}$ \\
\hline $\begin{array}{l}\text { Gelendzhik - the } \\
\text { beginning of the bypass } \\
\text { of the village of } \\
\text { Kabardinka }\end{array}$ & 5.85 & $\begin{array}{c}4000- \\
3750\end{array}$ & $\begin{array}{c}15600- \\
14350\end{array}$ & $\begin{array}{c}4000- \\
3750\end{array}$ & $\begin{array}{c}20550- \\
18900\end{array}$ \\
\hline $\begin{array}{l}\text { Bypassing the village of } \\
\text { Kabardinka }\end{array}$ & 3.50 & $\begin{array}{c}2950- \\
2800\end{array}$ & $\begin{array}{c}10350- \\
9250\end{array}$ & $\begin{array}{c}400- \\
300\end{array}$ & $\begin{array}{c}13650- \\
13350 \\
\end{array}$ \\
\hline $\begin{array}{l}\text { The end of the village of } \\
\text { Kabardinka bypass - the } \\
\text { beginning of the city of } \\
\text { Novorossiysk }\end{array}$ & 9.70 & $\begin{array}{c}3150- \\
3200\end{array}$ & $\begin{array}{c}10650- \\
3150\end{array}$ & $\begin{array}{c}600- \\
600\end{array}$ & $\begin{array}{c}14400- \\
14000\end{array}$ \\
\hline $\begin{array}{l}\text { Novorossiysk (street } \\
\text { Sukhumskoe highway) }\end{array}$ & 5.86 & $\begin{array}{c}3600- \\
5850\end{array}$ & $\begin{array}{c}11850- \\
17750\end{array}$ & $\begin{array}{c}1900- \\
2250\end{array}$ & $\begin{array}{c}17350- \\
25850\end{array}$ \\
\hline \multicolumn{6}{|c|}{2015} \\
\hline $\begin{array}{l}\text { The beginning of the } \\
\text { route (Arkhipo-Osipovka } \\
\text { village) - Pshada village } \\
\text { adjoining the entrance to } \\
\text { Beregovoe village and } \\
\text { Betta village }\end{array}$ & 18.10 & $\begin{array}{c}3500- \\
3450\end{array}$ & $\begin{array}{c}10850- \\
10550\end{array}$ & 700 & $\begin{array}{c}15300- \\
14700\end{array}$ \\
\hline $\begin{array}{l}\text { Adjacent to the entrance } \\
\text { to the village of } \\
\text { Beregovoe and the } \\
\text { village of Betta - the } \\
\text { village of Vozrozhdenie }\end{array}$ & 23.20 & $\begin{array}{c}3650- \\
3750\end{array}$ & $\begin{array}{c}10750- \\
12800\end{array}$ & $\begin{array}{c}500- \\
600\end{array}$ & $\begin{array}{c}14900- \\
17150\end{array}$ \\
\hline $\begin{array}{l}\text { Village Vozrozhdenie - } \\
\text { Adjacent to the entrance }\end{array}$ & 3.50 & $\begin{array}{c}3900- \\
5000\end{array}$ & $\begin{array}{c}14250- \\
19700\end{array}$ & $\begin{array}{l}650- \\
1000\end{array}$ & $\begin{array}{c}18800- \\
25700\end{array}$ \\
\hline
\end{tabular}




\begin{tabular}{|c|c|c|c|c|c|}
\hline \multirow{2}{*}{ Track span name } & \multirow{2}{*}{$\begin{array}{l}\text { Length, } \\
\mathrm{km}\end{array}$} & \multicolumn{4}{|c|}{$\begin{array}{l}\text { Average annual daily traffic intensity, car / } \\
\text { day }\end{array}$} \\
\hline & & Freight & Cars & Buses & Total \\
\hline $\begin{array}{l}\text { to the village. } \\
\text { Divnomorskoe and the } \\
\text { village of Praskoveevka }\end{array}$ & & & & & \\
\hline $\begin{array}{l}\text { Adjacent to the entrance } \\
\text { to the village } \\
\text { Divnomorskoe and the } \\
\text { village of Praskoveevka - } \\
\text { the beginning of the } \\
\text { bypass of Gelendzhik }\end{array}$ & 1.40 & 6650 & 33550 & 2100 & 42300 \\
\hline Bypass of Gelendzhik & 7.75 & 8600 & 39400 & 1400 & 49400 \\
\hline Gelendzhik & 1.65 & $\begin{array}{c}11250- \\
8200\end{array}$ & $\begin{array}{c}65900- \\
46850\end{array}$ & $\begin{array}{l}3600- \\
2000\end{array}$ & $\begin{array}{l}80750- \\
57050\end{array}$ \\
\hline $\begin{array}{l}\text { Gelendzhik - the } \\
\text { beginning of the bypass } \\
\text { of the village of } \\
\text { Kabardinka }\end{array}$ & 5.85 & $\begin{array}{c}7000- \\
6650\end{array}$ & $\begin{array}{c}32900- \\
30600\end{array}$ & $\begin{array}{c}1650- \\
1400\end{array}$ & $\begin{array}{c}41550- \\
38650\end{array}$ \\
\hline $\begin{array}{l}\text { Bypassing the village of } \\
\text { Kabardinka }\end{array}$ & 3.50 & $\begin{array}{c}5550- \\
5350\end{array}$ & $\begin{array}{c}23200- \\
21150\end{array}$ & $\begin{array}{c}750- \\
600\end{array}$ & $\begin{array}{c}29500- \\
27100\end{array}$ \\
\hline $\begin{array}{l}\text { The end of the village of } \\
\text { Kabardinka bypass - the } \\
\text { beginning of the city of } \\
\text { Novorossiysk }\end{array}$ & 9.70 & $\begin{array}{c}5950- \\
6050\end{array}$ & $\begin{array}{c}22950- \\
23000\end{array}$ & 1100 & $\begin{array}{c}30000- \\
30150\end{array}$ \\
\hline $\begin{array}{l}\text { Novorossiysk (street } \\
\text { Sukhumskoe highway) }\end{array}$ & 5.86 & $\begin{array}{c}6350- \\
9900\end{array}$ & $\begin{array}{c}25400- \\
36850\end{array}$ & $\begin{array}{c}3150- \\
3800\end{array}$ & $\begin{array}{c}34900- \\
50550\end{array}$ \\
\hline
\end{tabular}

Source: compiled by the author based on the research results

According to Table 3, it can be seen that the traffic intensity is decreasing, which leads to a change in road congestion. The bypass toll road has been shown to be effective in reducing the traffic flow.

\section{Conclusion}

There is a positive growth dynamic in the return of the effect in the future, which gives an opportunity to conclude that improving the roadsquality will lead to a decrease in road accidents, increase the mobility of the population, lead to the transitive potential development and, as a consequence, to the development of the region. The non-transport effect from improving road conditions in the field of non-material production is formed in a number of industries, which has a beneficial effect on the activities of the business sector and forms favorable institutional conditions for the development of the region. Of course, it is too early to talk about the return of funds for such roads' construction, since selfsufficiency for such projects is prolonged. And nevertheless, we can say with confidence about the need to implement such important and strategic objects, since thereby the road infrastructure is being formed, which affects the development of the entire Krasnodar Territory. 


\section{References}

1. Office of the Federal State Statistics Service for the Krasnodar Territory and the Republic of Adygea. https://krsdstat.gks.ru/

2. Z.M. Magrupova, A.S. Eremeeva, Problems of territory development 3 (71) (2014).

3. I.V. Topilin, IOP Conference Series: Materials Science and Engineering 913 (4), 042061 (2020). International Scientific Conference "Construction and Architecture: Theory and Practice of Innovative Development" (CATPID-2020. Part 1). 26-30 September 2020, Nalchik, Russian Federation.

4. I.A. Evstigneev, SAPR and GIS highways 2 (13), 44-50 (2019).

5. T.V. Zolotukhina, N.O. Fatakhutdinova, Region: systems, economics, management 4 (47), 54-58 (2019).

6. E.N. Sidorenko, O.A. Lykova, Private investment of infrastructure facilities in PPP projects and a mixed model of their return in the construction, IOP Conference Series: Materials Science and Engineering 698 (7), 077013 (2019). International Scientific Conference "Construction and Architecture: Theory and Practice of Innovative Development" 1-5 October 2019, Kislovodsk, Russian Federation.

7. E.A. Sidorenko, O.A. Lykova, Financial Economics 3, 651-655 (2019).

8. V.V. Zyryanov, S.E. Sorokin-Urmanov, Methods for determining the transport detectors' placement on road network, IOP Conference Series: Materials Science and Engineering 913 (4), 042063 (2020). International Scientific Conference "Construction and Architecture: Theory and Practice of Innovative Development" (CATPID-2020. Part 1.) 26-30 September 2020, Nalchik, Russian Federation).

9. O.A. Lykova, Institutional conditions for the formation and implementation of projects aimed at developing the regions road network, IOP Conference Series: Materials Science and Engineering 913 (5), 052010 (2020). International Scientific Conference "Construction and Architecture: Theory and Practice of Innovative Development" (CATPID-2020. Part 1) 26-30 September 2020, Nalchik, Russian Federation.

10. Feasibility study of the project "Comprehensive arrangement of the "M-4 Don" highway from Moscow through Voronezh, Rostov-on-Don, Krasnodar to Novorossiysk on the section km $1459+805-\mathrm{km} 1542+215$ in the Krasnodar Territory. 